\title{
Comparison of the effects of linseed oil and different doses of fish oil on mononuclear cell function in healthy human subjects
}

\author{
Fiona A. Wallace, Elizabeth A. Miles* and Philip C. Calder \\ Institute of Human Nutrition, School of Medicine, University of Southampton, \\ Bassett Crescent East, Southampton SO16 7PX, UK
}

(Received 6 June 2002 - Revised 14 November 2002 - Accepted 3 December 2002)

\begin{abstract}
Studies on animal and human subjects have shown that greatly increasing the amount of linseed (also known as flaxseed) oil (rich in the $n-3$ polyunsaturated fatty acid (PUFA) $\alpha$-linolenic acid (ALNA)) or fish oil (FO; rich in the long-chain $n$-3 PUFA eicosapentaenoic acid (EPA) and docosahexaenoic acid (DHA)) in the diet can decrease a number of markers of immune function. The immunological effects of more modest doses of $n-3$ PUFA in human subjects are unclear, dose-response relationships between $n-3$ PUFA supply and immune function have not been established and whether ALNA has the same effects as its long-chain derivatives is not known. Therefore, the objective of the present study was to determine the effect of enriching the diet with different doses of FO or with a modest dose of ALNA on a range of functional responses of human monocytes and lymphocytes. In a randomised, placebo-controlled, doubleblind, parallel study, forty healthy males aged 18-39 years were randomised to receive placebo or $3.5 \mathrm{~g} \mathrm{ALNA} / \mathrm{d}$ or $0.44,0.94$ or $1.9 \mathrm{~g}(\mathrm{EPA}+\mathrm{DHA}) / \mathrm{d}$ in capsules for 12 weeks. The EPA:DHA ratio in the FO used was 1.0:2.5. ALNA supplementation increased the proportion of EPA but not DHA in plasma phospholipids. FO supplementation decreased the proportions of linoleic acid and arachidonic acid and increased the proportions of EPA and DHA in plasma phospholipids. The interventions did not alter circulating mononuclear cell subsets or the production of tumour necrosis factor- $\alpha$, interleukin (IL) $1 \beta$, IL-2, IL-4, IL-10 or interferon- $\gamma$ by stimulated mononuclear cells. There was little effect of the interventions on lymphocyte proliferation. The two higher doses of FO resulted in a significant decrease in IL-6 production by stimulated mononuclear cells. It is concluded that, with the exception of IL-6 production, a modest increase in intake of either ALNA or EPA+DHA does not influence the functional activity of mononuclear cells. The threshold of EPA+DHA intake that results in decreased IL-6 production is between 0.44 and $0.94 \mathrm{~g} / \mathrm{d}$.
\end{abstract}

Fish oil: Linseed oil: $\alpha$-Linolenic acid: $n$-3 Polyunsaturated fatty acids: Immunity: Lymphocyte: Monocyte: Cytokine

Monocytes and lymphocytes form part of the immune response that is responsible for host defence against invading pathogens. Bacterial cell wall components such as lipopolysaccharide (LPS) stimulate the production by monocytes of cytokines, such as tumour necrosis factor (TNF) and interleukins (IL) 1 and 6. These inflammatory cytokines provide one link between the innate and specific immune systems as they can stimulate $\mathrm{T}$ and $\mathrm{B}$ lymphocytes (Abbas et al. 1994). The interaction between these cell types also involves cell surface proteins, such as intercellular adhesion molecule (ICAM)-1 (CD54) and CD11b. When $\mathrm{T}$ lymphocytes are activated, they secrete cytokines and ultimately enter the cell cycle and divide (Abbas et al. 1994). This proliferation of lymphocytes leads to an increase in the number of antigen-specific lymphocytes. In cell culture, the stimulation and subsequent proliferation of $\mathrm{T}$ lymphocytes can be achieved by mitogens such as concanavalin A (ConA) (Licastro et al. 1993). T lymphocytes are classified into helper $\mathrm{T}$ cells, distinguished by the presence of the molecule CD4 on their surface, and cytotoxic $\mathrm{T}$ cells, distinguished by the presence of CD8 on their surface. T lymphocytes can also be sub-divided functionally according to the pattern of cytokines they produce. Type1 helper $\mathrm{T}$ lymphocytes produce $\mathrm{IL}-2$ and interferon

\footnotetext{
Abbreviations: ALNA, $\alpha$-linolenic acid; ARA, arachidonic acid; ConA, concanavalin A; DHA, docosahexaenoic acid; EPA, eicosapentaenoic acid; FO, fish oil; ICAM, intercellular adhesion molecule; IFN, interferon; IL, interleukin; LPS, lipopolysaccharide; PBMC, peripheral blood mononuclear cell; PUFA, polyunsaturated fatty acid; TBARS, thiobarbituric acid-reactive substances; TNF, tumour necrosis factor.
}

* Corresponding author: Dr E. A. Miles, fax +44 238059 4383, email eam@soton.ac.uk 
(IFN)- $\gamma$, while type-2 helper T lymphocytes produce IL-4, -5 and -10 (Abbas et al. 1994), although T cells are not the only sources of these cytokines.

Over the last 10 years there has been increasing interest in the effects of $n-3$ polyunsaturated fatty acids (PUFA) on human immune function (for reviews, see Calder, 2001a,b). Studies have been short and have focused on the effects of the longer-chain $n$-3 PUFA eicosapentaenoic acid (EPA; $20: 5 n-3)$ and docosahexaenoic acid (DHA; 22:6n-3) found in fish oil (FO), rather than on those of the precursor $\alpha$-linolenic acid (ALNA; 18:3n-3). FO, providing $>2.4 \mathrm{~g}$ $(\mathrm{EPA}+\mathrm{DHA}) / \mathrm{d}$ decreased the production of TNF- $\alpha$, IL-1 $\beta$ and IL- 6 by LPS-stimulated mononuclear cells (Endres et al. 1989; Meydani et al. 1991b; Gallai et al. 1993; Caughey et al. 1996), decreased lymphocyte proliferation (Meydani et al. 1991b; Virella et al. 1991; Endres et al. 1993; Gallai et al. 1993) and decreased the production of IL-2 (Meydani et al. 1991b, 1993; Molvig et al. 1991; Virella et al. 1991; Endres et al. 1993; Gallai et al. 1993) and IFN- $\gamma$ (Gallai et al. 1993). Although some studies using lower doses of EPA + DHA revealed limited immunological impact (Cooper et al. 1993; Schmidt et al. 1996; Blok et al. 1997; Thies et al. $2001 a, b)$, there has been no attempt to define the doseresponse relationship between provision of EPA + DHA and immune function. Only a few studies have investigated the immunological effects of ALNA in human subjects. Increasing the amount of ALNA in the diet to about $14 \mathrm{~g} / \mathrm{d}$ for 4 weeks resulted in a significant decrease in TNF- $\alpha$ and IL- $1 \beta$ production by LPS-stimulated mononuclear cells (Caughey et al. 1996), while $18 \mathrm{~g}$ ALNA/d for 8 weeks resulted in a significant decrease in ConAstimulated lymphocyte proliferation (Kelley et al. 1991). There has been only one investigation of the influence of a modest dose of ALNA $(2 \mathrm{~g} / \mathrm{d})$ on mononuclear cell function (Thies et al. 2001a,b). In addition, apart from the studies of Thies et al. $(2001 a, b)$, using a modest dose of ALNA, and of Caughey et al. (1996), using a very high dose of ALNA, there has been no direct comparison of the immunological effects of ALNA and EPA + DHA. Most often, the finding that $n-3$ PUFA diminish inflammatory and immune cell functions is interpreted in a favourable way, with the conclusion that they are antiinflammatory and so will be beneficial to health (Calder, 2002). However, since these cells are the cellular components of the immune system, a reduction in their activities could compromise host defence. There are recommendations to increase the intake of $n$-3 PUFA in adults because of their beneficial health effects (British Nutrition Foundation, 1992, 1999; de Decekere et al. 1998). However, the studies described earlier suggest that potentially detrimental immunological effects can occur at high ALNA and EPA + DHA intakes. It is important to understand more about the immunological effects of lower doses of $n$-3 PUFA, to identify doseresponse relationships, and to determine whether ALNA and its long-chain derivatives have similar effects. Therefore, the current study compared the immunological effects of supplementation of the diet of healthy subjects with a modest dose of ALNA or with three doses of $\mathrm{EPA}+\mathrm{DHA}$.

\section{Subjects and methods}

Materials

PBS tablets were obtained from Unipath Ltd, Basingstoke, Hants., UK. Histopaque, 4-(2-hydroxyethly)-1-piperazineethanesulfonic acid-buffered Roswell Park Memorial Institute medium, glutamine, antibiotics (penicillin and streptomycin), ConA, Escherichia coli 0111:B4, LPS, boron trifluoride, formaldehyde, solvents and standard chemicals were purchased from Sigma Chemical Co. Ltd (Poole, Dorset, UK). Fluorescein isothiocyanate-labelled mouse anti-human CD3, CD14 and CD19 and R-phycoerythrin-labelled mouse anti-human CD4, CD8, CD11b, CD16 and CD54 were purchased from Serotec Ltd (Kidlington, Oxon., UK). $\left[{ }^{3} \mathrm{H}\right]$ Thymidine was purchased from Amersham International Ltd (Amersham, Bucks., UK). Cytokine EASIA ${ }^{\mathrm{TM}}$ ELISA kits were obtained from BioSource (Nivelles, Belgium).

\section{Subjects and study design}

Ethical permission for all procedures involving human volunteers was obtained from the Southampton and South West Hampshire Joint Ethics Committee. Healthy adults aged 18-39 years were invited to participate in the study. All volunteers completed a health and lifestyle questionnaire prior to entering the study, and doctor's consent for inclusion into the study was obtained. Volunteers were excluded if they were taking any prescribed medication, were vegetarian, consumed FO, evening primrose oil or vitamin supplements, smoked more than ten cigarettes per d, drank more than ten units of alcohol per week, had a BMI $>32 \mathrm{~kg} / \mathrm{m}^{2}$, or consumed more than two portions of oily fish per week. Blood pressure was measured in a sitting position using a commercially available monitor. Forty subjects were recruited to the study and all completed it. Plasma triacylglycerol concentrations were measured using a commercially available colorimetric assay (procedure no. 2337; Sigma Chemical Co.). The characteristics of the subjects are given in Table 1; mean age, BMI, blood pressure and fasting plasma triacylglycerol concentration did not differ among the treatment groups at study entry.

Subjects were randomly allocated in a double-blind fashion to one of five intervention groups ( $n 8$ per group). Each group consumed nine $1 \mathrm{~g}$ capsules per $\mathrm{d}$ for 12 weeks. This period was chosen because previous studies have demonstrated significant effects of $n$-3 PUFA supplementation on proliferation and cytokine production by mononuclear cells by 12 weeks (Endres et al. 1989, 1993; Meydani et al. 1991b; Molvig et al. 1991; Gallai et al. 1993; Caughey et al. 1996; Kelley et al. 1998, 1999; Thies et al. 2001b). The capsules used were generously provided by Scotia Pharmaceuticals Ltd, Carlisle, Cumbria, UK. The placebo group consumed capsules containing palm oil-soyabean oil $(80: 20, \mathrm{w} / \mathrm{w})$; this mix has a fatty acid composition that closely resembles that of the average UK diet (British Nutrition Foundation 1992, 1999). The ALNA group consumed capsules containing linseed (also known as flaxseed) oil, which provided $3.5 \mathrm{~g}$ ALNA/d. The other three groups consumed blends 
Table 1. Characteristics of treatment groups at baseline (week 0$)^{*}$

(Mean values with their standard errors for eight subjects per treatment group)

\begin{tabular}{|c|c|c|c|c|c|c|c|c|c|c|}
\hline \multirow{2}{*}{ Treatment group... } & \multicolumn{2}{|c|}{ Placebo } & \multicolumn{2}{|c|}{ ALNA } & \multicolumn{2}{|c|}{ Low-FO } & \multicolumn{2}{|c|}{ Medium-FO } & \multicolumn{2}{|c|}{ High-FO } \\
\hline & Mean & SEM & Mean & SEM & Mean & SEM & Mean & SEM & Mean & SEM \\
\hline Age (years) & $25 \cdot 8$ & 2.5 & $22 \cdot 7$ & $2 \cdot 0$ & $24 \cdot 8$ & 1.4 & $25 \cdot 1$ & 2.5 & $22 \cdot 0$ & $1 \cdot 2$ \\
\hline Height $(m)$ & 1.79 & 0.02 & 1.89 & 0.02 & 1.79 & 0.02 & 1.79 & 0.02 & 1.78 & 0.02 \\
\hline Weight (kg) & $74 \cdot 8$ & 3.2 & $80 \cdot 8$ & $5 \cdot 0$ & $75 \cdot 2$ & $3 \cdot 1$ & $70 \cdot 1$ & 3.1 & $72 \cdot 5$ & 4.3 \\
\hline $\operatorname{BMI}\left(\mathrm{kg} / \mathrm{m}^{2}\right)$ & $23 \cdot 2$ & 0.7 & 22.5 & $1 \cdot 1$ & 23.5 & 0.9 & $22 \cdot 3$ & 0.8 & $22 \cdot 8$ & 1.3 \\
\hline Systolic blood pressure (mmHg) & 124 & 3 & 122 & 4 & 125 & 5 & 120 & 4 & 129 & 2 \\
\hline Diastolic blood pressure $(\mathrm{mmHg})$ & 74 & 2 & 69 & 2 & 73 & 3 & 71 & 2 & 76 & 2 \\
\hline Plasma triacylgycerol $(\mathrm{mmol} / \mathrm{l})$ & $1 \cdot 1$ & 0.2 & 1.0 & 2 & $1 \cdot 1$ & 0.2 & 1.3 & 0.4 & 1.0 & 0.1 \\
\hline
\end{tabular}

ALNA, $\alpha$-linolenic acid; FO, fish oil.

${ }^{*}$ For details of treatments, see p. 680.

of the placebo and tuna oils providing $0.44,0.94$ and $1.9 \mathrm{~g}$ $(\mathrm{EPA}+\mathrm{DHA}) / \mathrm{d}$; these are referred to as low-, mediumand high-FO groups. The EPA:DHA ratio in the tuna oil was approximately $1 \cdot 0: 2 \cdot 5$. The fatty acid compositions of the capsules are shown in Table 2. The levels of EPA + DHA used were selected to represent an intake that could be achieved through supplementation of the habitual diet with one typical FO capsule per d (approximately $0.4 \mathrm{~g} / \mathrm{d}$ ), the intake of long-chain $n-3$ PUFA recommended by the British Nutrition Foundation (1999) (approximately $1 \mathrm{~g} / \mathrm{d}$ ), and the intake of long-chain $n$-3 PUFA provided by one oily fish meal/d (approximately $2 \mathrm{~g} / \mathrm{d}$; British Nutrition Foundation, 1999). The metabolic equivalence of ALNA:EPA has been assumed to be approximately 7 (Sanders \& Roshanai, 1983; Indu \& Ghafoorunissa, 1992; Emken et al. 1994). Thus, the level of ALNA used in the current study $(3.5 \mathrm{~g} / \mathrm{d})$ was selected to match the intake of EPA in the high-FO group, assuming a metabolic equivalence of approximately 7 and taking into account habitual intake of these two fatty acids. Each capsule contained $1 \mathrm{mg} \alpha$-tocopherol. Capsules were provided to subjects in tubs, each containing 300 capsules. Tubs were returned every 4 weeks and weighed to assess compliance; subjects were unaware of this procedure. Mean compliance was $>90 \%$ across all treatment groups and was not significantly different among groups. All treatment groups completed the study in parallel. The study ran from January 1998 (mid-winter) to April 1998 (early spring). Blood was collected immediately prior to beginning the interventions and at 12 weeks. Heparinised vacutainer tubes were used for blood collection, which was between 08.00 and $10.00 \mathrm{~h}$ after a fast of $\geqq 10 \mathrm{~h}$.

\section{Analysis of habitual nutrient intakes}

Subjects completed two $5 \mathrm{~d}$ food diaries separated by 8 weeks. Habitual nutrient intakes were determined using FOODBASE, version 1.3 (Institute of Brain Chemistry, London, UK).

\section{Analysis of plasma thiobarbituric acid-reactive substances and $\alpha$-tocopherol concentrations}

Plasma thiobarbituric acid-reactive substances (TBARS) concentrations were measured by incubating $100 \mu \mathrm{l}$ plasma with $1.2 \mathrm{ml}$ thiobarbituric acid $(3.35 \mathrm{~g} / 1 \mathrm{TCA}$ $(100 \mathrm{~g} / \mathrm{l}))$ for $15 \mathrm{~min}$ at $95^{\circ} \mathrm{C}$ and recording the absorbance at $535 \mathrm{~nm}$ after cooling; TBARS concentrations were calculated using an extinction coefficient of $1.56 \times 10^{4}(\mathrm{mmol} /$ $1)^{-1} / \mathrm{mm}$. Prior to determination of $\alpha$-tocopherol concentrations, plasma $(100 \mu \mathrm{l})$ was vortexed with methanol and diethyl ether, then centrifuged for $5 \mathrm{~min}$ at $3000 \mathrm{~g}$. The upper layer was evaporated to dryness under $\mathrm{N}_{2}$ and then reconstituted with methanol; the concentration of $\alpha$-tocopherol was then analysed by normal phase HPLC using a Varian 9095 delivery system, Varian 9050 u.v.

Table 2. Fatty acid composition of the capsules used

\begin{tabular}{|c|c|c|c|c|c|c|c|c|c|c|}
\hline \multirow{2}{*}{ Treatment group... } & \multicolumn{2}{|c|}{ Placebo } & \multicolumn{2}{|l|}{ ALNA } & \multicolumn{2}{|c|}{ Low-FO } & \multicolumn{2}{|c|}{ Medium-FO } & \multicolumn{2}{|c|}{ High-FO } \\
\hline & $\begin{array}{l}\mathrm{g} / 100 \mathrm{~g} \text { total } \\
\text { fatty acids }\end{array}$ & $g / d$ & $\begin{array}{l}\mathrm{g} / 100 \mathrm{~g} \text { total } \\
\text { fatty acids }\end{array}$ & $g / d$ & $\begin{array}{l}\mathrm{g} / 100 \mathrm{~g} \text { total } \\
\text { fatty acids }\end{array}$ & $g / d$ & $\begin{array}{l}\mathrm{g} / 100 \mathrm{~g} \text { total } \\
\text { fatty acids }\end{array}$ & $g / d$ & $\begin{array}{l}\mathrm{g} / 100 \mathrm{~g} \text { total } \\
\text { fatty acids }\end{array}$ & $g / d$ \\
\hline Myristic acid & $2 \cdot 1$ & 0.16 & 0.4 & 0.03 & $5 \cdot 1$ & 0.39 & 4.9 & 0.37 & $6 \cdot 0$ & 0.46 \\
\hline Palmitic acid & 34.9 & $2 \cdot 67$ & $7 \cdot 0$ & 0.53 & $30 \cdot 3$ & 2.32 & $29 \cdot 6$ & $2 \cdot 26$ & $22 \cdot 8$ & 1.74 \\
\hline Palmitoleic acid & $2 \cdot 0$ & 0.15 & 0.2 & 0.01 & $3 \cdot 3$ & 0.26 & $4 \cdot 3$ & 0.33 & $5 \cdot 3$ & 0.40 \\
\hline Stearic acid & 3.7 & 0.29 & 6.5 & 0.49 & 4.5 & 0.34 & $5 \cdot 0$ & 0.38 & 6.7 & 0.53 \\
\hline Oleic acid & 33.8 & 2.58 & $18 \cdot 9$ & 1.45 & $27 \cdot 3$ & 2.09 & $25 \cdot 2$ & 1.92 & $15 \cdot 5$ & 1.19 \\
\hline Linoleic acid & $18 \cdot 9$ & 1.45 & $16 \cdot 9$ & 1.29 & 14.4 & 1.11 & $12 \cdot 0$ & 0.91 & 2.4 & 0.18 \\
\hline ALNA & 1.8 & 0.14 & $45 \cdot 9$ & 3.51 & $2 \cdot 3$ & 0.18 & $2 \cdot 1$ & $0 \cdot 16$ & 1.6 & 0.13 \\
\hline ARA & 0 & 0 & $1 \cdot 7$ & 0.13 & 0 & 0 & $2 \cdot 2$ & 0.17 & $2 \cdot 3$ & 0.18 \\
\hline EPA & 0 & 0 & 0 & 0 & 1.9 & 0.15 & 3.3 & 0.27 & $6 \cdot 4$ & 0.49 \\
\hline $\mathrm{DHA}$ & 0 & 0 & 0 & 0 & 3.7 & 0.29 & 8.7 & 0.67 & 18.5 & 1.41 \\
\hline
\end{tabular}

ALNA, $\alpha$-linolenic acid; FO, fish oil; ARA, arachidonic acid; EPA, eicosapentaenoic acid; DHA, docosahexaenoic acid. 
detector and Varian 9012 pump on an Apex II $4.6 \mathrm{~m} \times$ $150 \mathrm{~mm}$ analytical column, with a flow rate of $2.5 \mathrm{ml} / \mathrm{min}$ and mobile phase consisting of water-methanol $(4 \cdot 5: 95 \cdot 5$, v/v) (Varian, Palo Alto, CA, USA). HPLC analysis was performed by the Chemical Pathology Laboratory of the Southampton University Hospitals NHS Trust (Southampton General Hospital, Southampton, Hants., UK).

\section{Analysis of plasma phospholipid fatty acid composition}

Lipid was extracted from plasma with chloroform-methanol $(2: 1, \mathrm{v} / \mathrm{v})$ and phospholipids isolated by TLC using hexane-diethyl ether-acetic acid (90:30:1, by vol.) as the elution phase. Fatty acid methyl esters were prepared by incubation with $140 \mathrm{~g}$ boron trifluoride/l methanol at $80^{\circ} \mathrm{C}$ for $60 \mathrm{~min}$. Fatty acid methyl esters were isolated by solvent extraction, dried and separated in a HewlettPackard 6890 GC (Hewlett Packard, Avondale, PA, USA) fitted with a $30 \mathrm{~m} \times 0.32 \mathrm{~mm}$ BPX70 capillary column, film thickness $0.25 \mu \mathrm{m}$. The carrier gas was He at $1.0 \mathrm{ml} / \mathrm{min}$ and the split-splitless injector was used with a split: splitless ratio of 20:1. Injector and detector temperatures were $275^{\circ} \mathrm{C}$. The column oven temperature was maintained at $170^{\circ} \mathrm{C}$ for $12 \mathrm{~min}$ after sample injection and was programmed to then increase from 170 to $210^{\circ} \mathrm{C}$ at $5^{\circ} \mathrm{C} / \mathrm{min}$ before being maintained at $210^{\circ} \mathrm{C}$ for $15 \mathrm{~min}$. The separation was recorded with HP GC Chem Station software (Hewlett Packard). Fatty acid methyl esters were identified by comparison with standards run previously.

\section{Preparation of peripheral blood mononuclear cells}

Blood was layered onto Histopaque (density $1.077 \mathrm{~g} / \mathrm{l}$; blood-Histopaque $1: 1, \mathrm{v} / \mathrm{v}$ ) and centrifuged for $15 \mathrm{~min}$ at $800 \mathrm{~g}$ at $20^{\circ} \mathrm{C}$. The cells (termed peripheral blood mononuclear cells, PBMC) were collected from the interphase and washed once with Roswell Park Medical Institute medium containing $2 \mathrm{~mm}$-glutamine and antibiotics (penicillin and streptomycin) (culture medium). The cells were then resuspended in $4 \mathrm{ml}$ culture medium and layered onto $4 \mathrm{ml}$ Histopaque. They were centrifuged again to achieve a lower degree of erythrocyte contamination, washed with culture medium and finally resuspended and counted on a Coulter Z1 Cell Counter (Coulter Electronics, Luton, Essex, UK).

\section{Analysis of peripheral blood mononuclear cells subsets}

Whole blood $(100 \mu \mathrm{l})$ was incubated with various combinations of fluorescently labelled monoclonal antibodies ( $10 \mu \mathrm{l}$ of each antibody) for $30 \mathrm{~min}$ at $4^{\circ} \mathrm{C}$. Monoclonal antibody combinations used were anti-CD3/anti-CD4 (to distinguish $\mathrm{T}$ lymphocytes as $\mathrm{CD}^{+}$and $\mathrm{T}$ helper lymphocytes as $\mathrm{CD}^{+} \mathrm{CD}^{+}$), anti-CD3/anti-CD8 (to distinguish cytotoxic $\mathrm{T}$ lymphocytes as $\mathrm{CD}^{+} \mathrm{CD} 8^{+}$), anti-CD3/anti-CD54 (to distinguish ICAM-1 expressing $\mathrm{T}$ lymphocytes), anti-CD3/anti-CD11b (to distinguish CD11b expressing $\mathrm{T}$ lymphocytes), anti-CD3/anti-CD16 (to distinguish natural killer cells as $\mathrm{CD}^{-} \mathrm{CD}^{+} 6^{+}$), anti-CD19/anti-CD54 (to distinguish B lymphocytes as $\mathrm{CD}_{1}{ }^{+}$and to determine the expression of ICAM-1
(CD54) on B lymphocytes), anti-CD19/anti-CD11b (to distinguish CD11b expressing B lymphocytes), anti-CD14/ anti-CD54 (to distinguish monocytes as $\mathrm{CD}^{+} 4^{+}$and to determine the expression of ICAM-1 on monocytes) and anti-CD14/anti-CD11b (to distinguish CD11b expressing monocytes). Erythrocytes were then lysed using $2 \mathrm{ml}$ lysing solution $(3.7 \mathrm{ml}$ formaldehyde, $4.5 \mathrm{ml}$ diethylene glycol, $1.75 \mathrm{ml} 0.2 \mathrm{M}$-Tris made up to 1 litre with distilled water) and leucocytes washed and then fixed with $0.2 \mathrm{ml}$ fixing solution $(20 \mathrm{ml}$ formaldehyde/l PBS). Fixed leucocytes were analysed in a Becton Dickinson FACSCalibur flow cytometer (Becton Dickinson, Oxford, Oxon, UK). Fluorescence data were collected on 5000 cells. Lymphocytes and monocytes were identified by forward and side scatter properties. Data were analysed using Cellquest software (Becton Dickinson, Oxford, Oxon, UK).

\section{Measurement of lymphocyte proliferation peripheral blood mononuclear cell cultures}

PBMC $\left(2 \times 10^{5}\right)$ were cultured at $37^{\circ} \mathrm{C}$ in culture medium supplemented with autologous plasma $(50 \mathrm{ml} / \mathrm{l})$ and ConA at final concentrations of $7 \cdot 5,15 \cdot 0,25 \cdot 0,50 \cdot 0$ and $75 \cdot 0 \mu \mathrm{g} /$ $\mathrm{ml}$; the final volume of the culture was $200 \mu \mathrm{l}$ and all cultures were performed in triplicate. Proliferation was measured as the incorporation of $\left[{ }^{3} \mathrm{H}\right]$ thymidine over the final $18 \mathrm{~h}$ of a $66 \mathrm{~h}$ culture period. Thymidine incorporation values for the triplicate cultures were averaged $(\mathrm{CV}<10 \%$ and usually $<5 \%$ ). Results are expressed as thymidine incorporation (cpm) per well.

\section{Measurement of the production of cytokines by peripheral blood mononuclear cell cultures}

PBMC $\left(2 \times 10^{6}\right)$ were cultured at $37^{\circ} \mathrm{C}$ for $24 \mathrm{~h}$ in culture medium, supplemented with autologous plasma $(50 \mathrm{ml} / \mathrm{l})$ and either ConA $(25 \mu \mathrm{g} / \mathrm{ml})$ or LPS $(15 \mu \mathrm{g} / \mathrm{ml})$; the final culture volume was $2 \mathrm{ml}$. Preliminary studies indicated that these concentrations of stimulants gave rise to the maximal concentrations of the cytokines under study and that the concentrations of all cytokines measured were maximal at $24 \mathrm{~h}$ of culture. At the end of the incubation, the plates were centrifuged and the culture medium collected and frozen in portions. The concentrations of cytokines were measured by specific EASIA ${ }^{\mathrm{TM}}$ ELISA kits (BioSource). TNF- $\alpha$, IL-1 $\beta$ and IL-6 were measured in the supernatant fractions of cells stimulated with LPS, and IL-2, IFN- $\gamma$, IL-4 and IL-10 were measured in the supernatant fractions of cells stimulated with ConA. Limits of detection for these assays were $3 \mathrm{pg} / \mathrm{ml}$ (TNF$\alpha), 2 \mathrm{pg} / \mathrm{ml}$ (IL-1 $\beta$, IL-6, IL-4), 1 pg/ml (IL-10), $0 \cdot 1 \mathrm{U} / \mathrm{ml}$ (IL-2) and $0.03 \mathrm{IU} / \mathrm{ml}$ (IFN- $\gamma$ ) (data supplied by the manufacturer of the kits). The inter- and intra-assay $\mathrm{CV}$ were $<10 \%$ for all cytokine ELISA.

\section{Statistical analysis}

Sample size (i.e. number of subjects per treatment group) was calculated on the basis of measurements made previously in this laboratory using the same methods as those used in this study and of existing results from the 
literature that reported significant effects of long chain $n-3$ PUFA supplementation on lymphocyte proliferation and cytokine production (Endres et al. 1989, 1993; Meydani et al. 1991b; Molvig et al. 1991; Kelley et al. 1998, 1999; Thies et al. 2001b). It was determined that a sample size of eight would detect a difference in lymphocyte proliferation and cytokine production of $>25 \%$ at $P<0.05$ with $80 \%$ power.

Data for each treatment group at each time point were tested for normality using the Kolmogorov-Smirnov test. All data were normally distributed and so are presented as mean values with their standard errors. One-way ANOVA was used to determine differences among treatment groups at baseline (weeks 0) and at the end of supplementation (weeks 12). Student's paired $t$ test was used to determine differences within each treatment group across time. Bonferroni's correction for multiple comparisons was used in all statistical analyses. All statistical tests were performed using SPSS, version 10.0 (SPSS Inc., Chicago, IL, USA) and a value of $P<0.05$ was taken to indicate statistical significance.

\section{Results}

\section{Habitual nutrient intakes}

Habitual nutrient intakes determined from two separate $5 \mathrm{~d}$ food diaries completed 8 weeks apart did not differ significantly (paired Student's $t$ test) and so the data were averaged. There were no significant differences among treatment groups with respect to habitual intakes of total energy (10.6 (SEM 0.4) MJ/d for all subjects $(n$ 40)) and energy from fat, carbohydrate and protein (33.6 (SEM $0.9), 45.5$ (SEM 0.8 ) and 14.8 (SEM $0 \cdot 3$ ) \% respectively) or of $\alpha$-tocopherol (9 (SEM 1) $\mathrm{mg} / \mathrm{d}$ ). Habitual intakes of individual fatty acids did not differ among the treatment groups; results for all subjects combined are shown in Table 3. Likewise, habitual intakes of total saturated fatty acids, total monounsaturated fatty acids, total PUFA, total $n$-6 PUFA and total $n$-3 PUFA did not differ among treatment groups (results not shown).

\section{Fatty acid intakes during treatment}

Intakes of individual fatty acids during the period of treatment with the supplements were calculated by adding habitual intakes to intakes due to the supplements (Table 3). Although intakes of palmitic (16:0), palmitoleic $(16: 1 n-7)$, oleic $(18: 1 n-9)$ and linoleic $(18: 2 n-6)$ acids were increased slightly in at least some treatment groups during supplementation, they were not significantly different from habitual intakes. Furthermore, during supplementation intakes of these fatty acids were not different among the treatment groups (Table 3). In contrast, supplementation affected the intakes of ALNA, arachidonic acid (ARA; 20:4n-6), EPA and DHA, such that there were significant differences in the intakes of these fatty acids among the different treatment groups (Table 3)

\section{Plasma thiobarbituric acid-reactive substances and $\alpha$-tocopherol concentrations}

Plasma TBARS concentration did not differ among the treatment groups at baseline (5.12 (SEM 0.16) $\mu \mathrm{mol} / \mathrm{l}, n$ 40) or at the end of supplementation (results not shown). Plasma $\alpha$-tocopherol concentration did not differ among the treatment groups at baseline (15.9 (SEM 0.6) $\mu \mathrm{mol} / \mathrm{l}$, $n$ 40). Plasma $\alpha$-tocopherol concentration increased significantly in all groups during treatment $(P<0.05 v$. baseline; paired Student's $t$ test). However, there was no difference in plasma $\alpha$-tocopherol concentration among treatment groups at the end of supplementation (22.0 (SEM 1.4) $\mu \mathrm{mol} / 1, n$ 40).

\section{Fatty acid composition of plasma phospholipids}

The fatty acid composition of plasma phospholipids did not differ among the treatment groups at baseline (Table 4), and was not affected by the placebo treatment (Table 4). None of the treatments significantly altered the proportions of palmitic (approximately $30 \mathrm{~g} / 100 \mathrm{~g}$ total fatty acids), stearic (approximately $15 \mathrm{~g} / 100 \mathrm{~g}$ total fatty acids) or oleic (approximately $12 \mathrm{~g} / 100 \mathrm{~g}$ total fatty acids) acids in

Table 3. Habitual fatty acid intakes $(\mathrm{g} / \mathrm{d})$ of all subjects at baseline and fatty acid intakes $(\mathrm{g} / \mathrm{d})$ of subjects in the different treatment groups during supplementation*

(Mean values with their standard errors for eight subjects per group)

\begin{tabular}{|c|c|c|c|c|c|c|c|c|c|c|c|c|}
\hline \multirow{2}{*}{ Treatment group. . } & \multicolumn{2}{|c|}{$\begin{array}{l}\text { All subjects } \\
\quad(n 40)\end{array}$} & \multicolumn{2}{|c|}{ Placebo } & \multicolumn{2}{|c|}{ ALNA } & \multicolumn{2}{|c|}{ Low-FO } & \multicolumn{2}{|c|}{ Medium-FO } & \multicolumn{2}{|c|}{ High-FO } \\
\hline & Mean & SEM & Mean & SEM & Mean & SEM & Mean & SEM & Mean & SEM & Mean & SEM \\
\hline Myristic acid & $3 \cdot 30$ & 0.20 & 3.39 & 0.40 & 3.65 & 0.45 & 3.42 & 0.60 & 3.69 & 0.30 & 3.85 & 0.56 \\
\hline Palmitic acid & $16 \cdot 15$ & 0.69 & $18 \cdot 42$ & 1.49 & $16 \cdot 94$ & $1 \cdot 17$ & $19 \cdot 23$ & $2 \cdot 35$ & $18 \cdot 12$ & 1.22 & $17 \cdot 59$ & 1.32 \\
\hline Palmitoleic acid & 1.15 & 0.05 & 1.19 & 0.14 & $1 \cdot 28$ & 0.09 & 1.37 & 0.15 & 1.53 & 0.09 & 1.54 & 0.11 \\
\hline Stearic acid & 7.41 & 0.36 & $6 \cdot 81$ & 0.67 & 8.04 & 0.49 & 8.25 & 1.31 & 7.95 & 0.73 & 8.02 & 0.50 \\
\hline Oleic acid & $22 \cdot 77$ & 0.05 & $24 \cdot 01$ & 1.84 & $23 \cdot 24$ & 2.50 & $27 \cdot 19$ & $2 \cdot 83$ & 24.58 & 1.73 & $23 \cdot 81$ & 1.81 \\
\hline Linoleic acid & 12.63 & 0.76 & 13.34 & 1.52 & 14.20 & 1.58 & 16.09 & 1.45 & 13.25 & 1.71 & 11.29 & $2 \cdot 10$ \\
\hline ALNA & 1.24 & 0.06 & $1.48^{\mathrm{a}}$ & 0.15 & $4 \cdot 66^{\mathrm{b}}$ & 0.14 & $1.64^{\mathrm{a}}$ & 0.14 & $1.38^{a}$ & 0.15 & $1 \cdot 12^{\mathrm{a}}$ & 0.11 \\
\hline ARA & 0.17 & 0.01 & $0 \cdot 18^{a}$ & 0.04 & $0.28^{\mathrm{ab}}$ & 0.02 & $0.17^{a}$ & 0.03 & $0.36^{b}$ & 0.03 & $0.33^{b}$ & 0.02 \\
\hline EPA & 0.07 & 0.01 & $0.06^{a}$ & 0.02 & $0.06^{a}$ & 0.02 & $0.23^{b}$ & 0.03 & $0.33^{c}$ & 0.03 & $0.56^{d}$ & 0.01 \\
\hline $\mathrm{DHA}$ & 0.13 & 0.02 & $0 \cdot 10^{a}$ & 0.02 & $0.06^{a}$ & 0.01 & $0.43^{b}$ & 0.05 & $0.75^{c}$ & 0.11 & $1.54^{d}$ & 0.02 \\
\hline
\end{tabular}

ALNA, $\alpha$-linolenic acid; FO, fish oil; ARA, arachidonic acid; EPA, eicosapentaenoic acid; DHA, docosahexaenoic acid

$\mathrm{a}, \mathrm{b}, \mathrm{c}, \mathrm{d}$ Mean values within a row with unlike superscript letters were significantly different (one-way ANOVA; $P<0.001$ )

${ }^{*}$ For details of subjects, supplements and procedures, see Tables 1 and 2, and p. 680. 
Table 4. Fatty acid composition of plasma phospholipids in the different treatment groups ( $\mathrm{g} / 100 \mathrm{~g}$ total fatty acids) $\ddagger$

(Mean values with their standard errors for eight subjects per group)

\begin{tabular}{|c|c|c|c|c|c|c|c|c|c|}
\hline \multirow[b]{2}{*}{ Treatment group } & \multirow[b]{2}{*}{ Time (weeks) } & \multicolumn{2}{|c|}{ Linoleic acid } & \multicolumn{2}{|c|}{ ARA } & \multicolumn{2}{|c|}{ EPA } & \multicolumn{2}{|c|}{$\mathrm{DHA}$} \\
\hline & & Mean & SEM & Mean & SEM & Mean & SEM & Mean & SEM \\
\hline \multirow[t]{2}{*}{ Placebo } & 0 & $22 \cdot 9$ & 0.8 & $8 \cdot 2$ & 0.5 & $1 \cdot 1$ & 0.2 & 3.8 & 0.3 \\
\hline & 12 & 24.4 & 1.1 & $8 \cdot 4$ & 0.5 & 0.8 & 0.3 & $4 \cdot 1$ & 0.3 \\
\hline \multirow{2}{*}{ ALNA } & 0 & $23 \cdot 6$ & 0.5 & 8.6 & 0.4 & 1.0 & 0.5 & 3.9 & 0.5 \\
\hline & 12 & $23 \cdot 3$ & 0.4 & 8.0 & 0.3 & $1.6^{*} \dagger$ & 0.3 & 4.0 & 0.4 \\
\hline \multirow[t]{2}{*}{ Low-FO } & 0 & 24.4 & $1 \cdot 1$ & $9 \cdot 2$ & 0.5 & 0.7 & 0.2 & 3.7 & 0.3 \\
\hline & 12 & 23.4 & $1 \cdot 3$ & $7 \cdot 4^{\mathrm{a}}$ & 0.4 & $1.5^{*} \dagger$ & 0.3 & $5.9^{*} \dagger$ & 0.7 \\
\hline \multirow[t]{2}{*}{ Medium-FO } & 0 & $23 \cdot 8$ & 1.0 & $7 \cdot 9$ & 0.4 & 0.7 & 0.3 & 3.9 & $0 \cdot 7$ \\
\hline & 12 & $21.9^{*} \dagger$ & 0.7 & $7 \cdot 0^{*} \dagger$ & 0.4 & $1.7^{\star} \dagger$ & 0.3 & $7 \cdot 8^{*} \dagger$ & 0.8 \\
\hline \multirow[t]{2}{*}{ High-FO } & 0 & $23 \cdot 3$ & 0.5 & 9.5 & 0.4 & 0.6 & 0.3 & 3.0 & 0.2 \\
\hline & 12 & $20.8^{*} \dagger$ & 1.4 & $8 \cdot 2^{*}$ & 0.7 & $2 \cdot 0^{*} \dagger$ & 0.6 & $6 \cdot 8^{*} \dagger$ & 0.5 \\
\hline
\end{tabular}

ARA, arachidonic acid; EPA, eicosapentaenoic acid; DHA, docosahexaenoic acid; ALNA, $\alpha$-linolenic acid; FO, fish oil. Mean values were significantly different from those at baseline (week 0 ) (paired $t$ test): ${ }^{\star} P<0.05$.

Mean values were significantly different from those of the placebo group (one-way ANOVA): $† P<0.05$.

$\ddagger$ For details of subjects, supplements and procedures, see Tables 1 and 2, and p. 680 .

plasma phospholipids. Consumption of ALNA did not result in significant appearance of ALNA in plasma phospholipids. However, ALNA consumption increased the proportion of EPA (by $60 \%$ ) such that the proportion was significantly $(P<0.05)$ greater than at baseline and significantly $(P<0.05)$ higher than that in the placebo group (Table 4$)$. ALNA consumption did not alter the proportion of DHA in plasma phospholipids (Table 4). Consumption of FO resulted in a significant $(P<0.05)$ decrease in the proportion of ARA in plasma phospholipids (maximum $25 \%$ decrease), although this did not appear to relate to the dose of EPA + DHA provided (Table 4). The medium and high doses of FO also resulted in a significant $(P<0.05)$ decrease (about $15 \%)$ in the proportion of linoleic acid in plasma phospholipids (Table 4). FO consumption caused a significant $(P<0.05)$ increase in the proportion of EPA in plasma phospholipids (Table 4). The observed increases in EPA content (approximately 115, 140 and $230 \%$ in the low-, mediumand high-FO groups respectively) were linearly related to the amount of EPA supplied in the capsules $(P=0.01$ for the relationship between change in EPA from baseline to weeks 12 and EPA intake from capsules). However, the proportion of EPA in plasma phospholipids was not different among the groups receiving different doses of FO at 12 weeks of treatment (Table 4). FO consumption caused a significant $(P<0.05)$ increase in the proportion of DHA in plasma phospholipids (Table 4). Although the increase was greater in the medium- and high-FO groups (100 and $125 \%$ respectively) than in the low-FO group ( $45 \%$ ), at 12 weeks of treatment there were no differences in the proportion of DHA in plasma phospholipids among the groups receiving the three different doses of FO (Table 4).

\section{Peripheral blood mononuclear cells subsets}

The proportions of lymphocytes as T lymphocytes, B lymphocytes or natural killer cells were not different among the treatment groups at baseline and were not significantly affected by the treatments (Table 5). Likewise, the proportions of $\mathrm{T}$ lymphocytes as helper or cytotoxic cells were not different among the treatment groups at baseline, and were not affected by the treatments (Table 5). The proportions of $\mathrm{T}$ lymphocytes expressing ICAM-1 (approximately 5\%) or CD11b (approximately $20 \%$ ), of B lymphocytes expressing ICAM-1 (approximately $60 \%$ ) or CD11b (approximately $70 \%$ ), and of monocytes expressing ICAM-1 (approximately 95\%) or CD11b (approximately 70\%) were not different among the treatment groups at baseline and were not affected by the treatments (results not shown).

\section{Cytokine production by peripheral blood mononuclear cells}

The production of TNF- $\alpha$ and IL-1 $\beta$ by PBMC stimulated with LPS $(15 \mu \mathrm{g} / \mathrm{ml})$ and the production of IL-2, IL-4, IFN$\gamma$ and IL-10 by PBMC stimulated with ConA $(25 \mu \mathrm{g} / \mathrm{ml})$ did not differ among the treatment groups at baseline or at the end of supplementation and did not differ between time points within any treatment group (Tables 6 and 7). However, production of IL-6 was decreased after 12 weeks in the medium- and high-FO groups, such that it was significantly $(P<0.05)$ lower than at baseline and significantly $(P<0.05)$ lower than that observed in the placebo group (Table 6). In the medium-FO group, the range of the decrease was $19-90 \%$ with a mean decrease of $65 \%$. In the high-FO group, the range of the decrease was $15-61 \%$ with a mean decrease of $40 \%$.

\section{Lymphocyte proliferation}

For all subjects, peak incorporation of thymidine occurred at a ConA concentration of $25 \mu \mathrm{g} / \mathrm{ml}$. Thymidine incorporation in response to each concentration of ConA used did not differ among treatment groups at baseline or at the end of supplementation (results for $25 \mu \mathrm{g} / \mathrm{ml}$ ConA are shown in Table 7). However, thymidine incorporation decreased with time in all groups, such that it was less at the end of supplementation than at baseline in each group (Table 7). 
Table 5. Peripheral blood mononuclear cell subsets in the different treatment groups* (Mean values with their standard errors for eight subjects per group)

\begin{tabular}{|c|c|c|c|c|c|c|c|c|c|c|c|}
\hline \multirow[b]{2}{*}{ Treatment group } & \multirow[b]{2}{*}{ Time (weeks) } & \multicolumn{2}{|c|}{ T cellst } & \multicolumn{2}{|c|}{$\begin{array}{l}\text { Helper T } \\
\text { cellsł }\end{array}$} & \multicolumn{2}{|c|}{$\begin{array}{l}\text { Cytotoxic T } \\
\text { cells§ }\end{array}$} & \multicolumn{2}{|c|}{ B cells\| } & \multicolumn{2}{|c|}{$\begin{array}{l}\text { Natural killer } \\
\text { cells } \|\end{array}$} \\
\hline & & Mean & SEM & Mean & SEM & Mean & SEM & Mean & SEM & Mean & SEM \\
\hline \multirow[t]{2}{*}{ Placebo } & 0 & $62 \cdot 4$ & 1.5 & $54 \cdot 3$ & 4.6 & 33.7 & 1.8 & 7.3 & 1.4 & $6 \cdot 7$ & 1.7 \\
\hline & 12 & $60 \cdot 6$ & 2.9 & $56 \cdot 1$ & 3.7 & 35.4 & 1.7 & $7 \cdot 8$ & 0.6 & $6 \cdot 7$ & 1.4 \\
\hline \multirow[t]{2}{*}{ ALNA } & 0 & 63.9 & $2 \cdot 7$ & 53.4 & $2 \cdot 7$ & 39.1 & $2 \cdot 8$ & $7 \cdot 6$ & 1.0 & 8.9 & 0.7 \\
\hline & 12 & $61 \cdot 8$ & 2.9 & 52.6 & $2 \cdot 8$ & $36 \cdot 7$ & $2 \cdot 1$ & 8.9 & 1.6 & $8 \cdot 1$ & 1.8 \\
\hline \multirow[t]{2}{*}{ Low-FO } & 0 & 67.9 & 4.5 & 57.9 & $3 \cdot 1$ & 32.5 & 1.9 & $6 \cdot 3$ & 0.7 & 5.5 & 1.7 \\
\hline & 12 & $60 \cdot 1$ & $2 \cdot 3$ & 58.9 & 2.4 & 29.9 & $2 \cdot 1$ & 8.4 & $1 \cdot 1$ & 4.9 & 1.0 \\
\hline \multirow[t]{2}{*}{ Medium-FO } & 0 & $64 \cdot 1$ & 3.6 & 49.7 & 4.9 & 38.2 & 3.4 & $6 \cdot 0$ & 1.2 & $6 \cdot 8$ & 1.9 \\
\hline & 12 & 63.2 & 3.9 & $52 \cdot 8$ & $2 \cdot 8$ & 38.5 & 2.9 & 8.4 & 0.7 & $6 \cdot 7$ & $1 \cdot 1$ \\
\hline \multirow[t]{2}{*}{ High-FO } & 0 & 64.5 & $2 \cdot 2$ & $58 \cdot 1$ & 2.5 & 34.4 & $2 \cdot 7$ & $7 \cdot 7$ & 1.4 & 9.2 & $2 \cdot 1$ \\
\hline & 12 & 57.9 & 3.2 & 57.4 & 1.8 & 35.3 & $2 \cdot 0$ & $10 \cdot 9$ & 1.5 & 9.3 & 1.8 \\
\hline
\end{tabular}

ALNA, $\alpha$-linolenic acid; FO, fish oil.

* For details of subjects, supplements and procedures, see Tables 1 and 2, and p. 680.

†Defined as: \% lymphocytes staining positive for CD3.

$\ddagger$ Defined as: \% $\mathrm{CD}^{+}$lymphocytes staining positive for CD4.

$\S$ Defined as: \% CD3 ${ }^{+}$lymphocytes staining positive for CD8.

|l Defined as: \% lymphocytes staining positive for CD19.

I Defined as: \% lymphocytes staining negative for CD3 and positive for CD16.

\section{Discussion}

A number of studies in healthy human volunteers have reported that long-chain $n-3$ PUFA diminish mononuclear cell functions (Endres et al. 1989, 1993; Meydani et al. 1991b, 1993; Molvig et al. 1991; Virella et al. 1991; Gallai et al. 1993; Caughey et al. 1996; Kelley et al. 1998, 1999), suggesting that FO could compromise host defence. However, since these studies have used FO providing 2.4-6.0 g (EPA + DHA)/d, they represent a $10-$ to $30-$ fold increase in EPA + DHA consumption. Likewise, some studies in healthy human subjects that examined the effects of ALNA on mononuclear cell functions used 14 or $18 \mathrm{~g}$ ALNA/d (Kelley et al. 1991; Caughey et al. 1996), which is at least 7-fold greater than the habitual intake of this fatty acid (British Nutrition Foundation, 1999). Relatively little is known about the effects of more modest consumption of $n$-3 PUFA on human mononuclear cell functions, or about dose-response relationships.
Furthermore, since there are few direct comparisons, it is not clear whether ALNA exerts the same effects as its long-chain derivatives. There are recommendations to increase intake of both ALNA and long-chain $n$-3 PUFA (British Nutrition Foundation, 1992, 1999; de Deckere et al. 1998). Thus, it is important to ensure that there is no adverse immunological impact of a more moderate increase in the consumption of these PUFA. Therefore, in the current study, the immunological effects of a modest increase in ALNA intake were compared with those of modest increases in EPA + DHA intake.

Subjects in the ALNA group consumed $3.5 \mathrm{~g}$ ALNA/d from the capsules, so increasing their daily intake by approximately $275 \%$. Although this did not alter the proportion of ALNA in plasma phospholipids, one product of ALNA elongation and desaturation (EPA) was significantly $(P<0.05)$ elevated. The lack of appearance of ALNA in plasma phospholipids following an increase in ALNA consumption is in accordance with several earlier

Table 6. Cytokine production $(\mathrm{ng} / \mathrm{ml})$ by peripheral blood mononuclear cells in response to lipopolysaccharide in the different treatment groups $\ddagger$

(Mean values with their standard errors for eight subjects per group)

\begin{tabular}{|c|c|c|c|c|c|c|c|}
\hline \multirow[b]{2}{*}{ Treatment group } & \multirow[b]{2}{*}{ Time (weeks) } & \multicolumn{2}{|c|}{ TNF- $\alpha$} & \multicolumn{2}{|c|}{$\mathrm{IL}-1 \beta$} & \multicolumn{2}{|c|}{ IL-6 } \\
\hline & & Mean & SEM & Mean & SEM & Mean & SEM \\
\hline \multirow[t]{2}{*}{ Placebo } & 0 & 5.08 & $1 \cdot 19$ & 8.50 & 1.81 & 48.5 & $6 \cdot 3$ \\
\hline & 12 & 5.90 & 0.84 & $8 \cdot 27$ & 0.97 & 44.9 & $5 \cdot 8$ \\
\hline \multirow[t]{2}{*}{ ALNA } & 0 & 5.59 & 0.94 & 6.43 & 1.61 & 46.9 & $7 \cdot 6$ \\
\hline & 12 & 6.60 & 0.77 & $7 \cdot 46$ & 0.93 & 44.9 & $8 \cdot 8$ \\
\hline \multirow[t]{2}{*}{ Low-FO } & 0 & $5 \cdot 12$ & 0.56 & $7 \cdot 72$ & $1 \cdot 37$ & $57 \cdot 1$ & 5.5 \\
\hline & 12 & 5.46 & 0.72 & $8 \cdot 27$ & 1.92 & $49 \cdot 7$ & $7 \cdot 6$ \\
\hline \multirow[t]{2}{*}{ Medium-FO } & 0 & $5 \cdot 41$ & 1.57 & $7 \cdot 29$ & 0.96 & $55 \cdot 2$ & 4.7 \\
\hline & 12 & $5 \cdot 62$ & 0.71 & 6.57 & 0.75 & $24 \cdot 6^{\star} \dagger$ & 4.5 \\
\hline \multirow[t]{2}{*}{ High-FO } & 0 & 5.45 & 1.09 & $7 \cdot 47$ & 1.08 & 58.9 & 5.4 \\
\hline & 12 & $6 \cdot 79$ & 0.83 & 6.75 & 0.88 & $36 \cdot 4^{*} \dagger$ & 2.9 \\
\hline
\end{tabular}

TNF, tumour necrosis factor; IL, interleukin; ALNA, $\alpha$-linolenic acid; FO, fish oil.

Mean values were significantly different from those at baseline (week 0 ) (paired $t$ test): ${ }^{*} P<0.05$.

Mean values were significantly different from those of the placebo group (one-way ANOVA): $† P<0.05$.

$\ddagger$ For details of subjects, supplements and procedures, see Tables 1 and 2 , and p. 680 . 
Table 7. Lymphocyte proliferation and cytokine production by peripheral blood mononuclear cells in response to concanavalin $\mathrm{A}$ $(25 \mu \mathrm{g} / \mathrm{ml})$ in the different treatment groups $\dagger$

(Mean values with their standard errors for eight subjects per group)

\begin{tabular}{|c|c|c|c|c|c|c|c|c|c|c|c|}
\hline \multirow{2}{*}{$\begin{array}{l}\text { Treatment } \\
\text { group }\end{array}$} & \multirow{2}{*}{$\begin{array}{c}\text { Time } \\
\text { (weeks) }\end{array}$} & \multicolumn{2}{|c|}{$\begin{array}{l}\text { Thymidine incor- } \\
\text { poration } \\
\text { (cpm/well) }\end{array}$} & \multicolumn{2}{|c|}{ IL-2 (U/ml) } & \multicolumn{2}{|c|}{$\mathrm{IFN}-\gamma(\mathrm{U} / \mathrm{ml})$} & \multicolumn{2}{|c|}{ IL-4 (pg/ml) } & \multicolumn{2}{|c|}{ IL-10 (pg/ml) } \\
\hline & & Mean & SEM & Mean & SEM & Mean & SEM & Mean & SEM & Mean & SEM \\
\hline \multirow[t]{2}{*}{ Placebo } & 0 & 52590 & 7947 & $12 \cdot 1$ & $3 \cdot 1$ & 244 & 108 & $13 \cdot 6$ & $2 \cdot 3$ & 257 & 60 \\
\hline & 12 & $32170^{*}$ & 5058 & $12 \cdot 6$ & $4 \cdot 7$ & 254 & 89 & 8.9 & 3.3 & 268 & 50 \\
\hline \multirow[t]{2}{*}{ ALNA } & 0 & 50392 & 5779 & 14.9 & 3.2 & 173 & 42 & $15 \cdot 2$ & 4.6 & 354 & 131 \\
\hline & 12 & $37720^{*}$ & 2612 & 14.5 & $2 \cdot 1$ & 183 & 41 & $14 \cdot 2$ & $3 \cdot 8$ & 328 & 100 \\
\hline \multirow[t]{2}{*}{ Low-FO } & 0 & 56553 & 7218 & 14.3 & 3.7 & 209 & 54 & $23 \cdot 6$ & $8 \cdot 7$ & 316 & 78 \\
\hline & 12 & $37024^{\star}$ & 1932 & $12 \cdot 6$ & $2 \cdot 4$ & 197 & 59 & $18 \cdot 4$ & $5 \cdot 6$ & 271 & 40 \\
\hline \multirow[t]{2}{*}{ Medium-FO } & 0 & 52004 & 5613 & 5.7 & 0.9 & 169 & 54 & $10 \cdot 9$ & 1.9 & 283 & 82 \\
\hline & 12 & $29004^{\star}$ & 4204 & $7 \cdot 9$ & 1.5 & 163 & 31 & $10 \cdot 6$ & 4.4 & 299 & 62 \\
\hline \multirow[t]{2}{*}{ High-FO } & 0 & 53826 & 5904 & $7 \cdot 6$ & $1 \cdot 2$ & 151 & 70 & 11.4 & 4.5 & 331 & 79 \\
\hline & 12 & $33581^{*}$ & 7618 & $6 \cdot 6$ & 1.0 & 198 & 43 & 14.4 & $6 \cdot 1$ & 412 & 103 \\
\hline
\end{tabular}

IL, interleukin; IFN, interferon; ALNA, $\alpha$-linolenic acid; FO, fish oil.

Mean values were significantly different from those at baseline (week 0) (paired $t$ test): ${ }^{\star} P<0.05$.

†For details of subjects, supplements and procedures, see Tables 1 and 2, and p. 680 .

studies, which suggest that substantial increases in ALNA intake are required before this fatty acid appears in plasma phospholipids (Mantzioris et al. 1994, 1995; Li et al. 1999; Thies et al. 2001c; Finnegan et al. 2003). The observed increase in the proportion of EPA in plasma phospholipids following chronic ALNA consumption has been reported previously (Sanders \& Younger, 1981; Mantzioris et al. 1994; Li et al. 1999; Finnegan et al. 2003). The current study found that the proportion of DHA was not increased after increased consumption of ALNA, suggesting that the EPA formed from ALNA is not further desaturated and elongated. The lack of change in the DHA content of plasma phospholipids after increased ALNA consumption is consistent with earlier studies (Sanders \& Younger, 1981; Li et al. 1999; Thies et al. 2001c; Finnegan et al. 2003). Despite the increase in ALNA intake and the altered plasma phospholipid EPA content, there was no change in lymphocyte proliferation or production of cytokines by monocytes and lymphocytes in the ALNA group. This in is contrast with studies using high doses of ALNA, in which decreased lymphocyte proliferation in response to ConA (Kelley et al. 1991) and decreased production of TNF- $\alpha$ and IL-1 $\beta$ by LPS-stimulated monocytes (Caughey et al. 1996) was reported. However, a recent study demonstrated that increasing ALNA intake by about $2 \mathrm{~g} / \mathrm{d}$ did not affect lymphocyte proliferation or the production of a range of cytokines by monocytes and lymphocytes (Thies et al. 2001a,b). The current study extends these earlier reports by demonstrating absence of effects of a higher ALNA intake on mononuclear cell functions. Furthermore, increasing ALNA intake by about $4 \mathrm{~g} / \mathrm{d}$ did not influence neutrophil chemotaxis or superoxide production (Healy et al. 2000). Taken together, these studies demonstrate that increasing ALNA intake to $4 \mathrm{~g} / \mathrm{d}$ is unlikely to have deleterious immunological effects. This is important, because there are recommendations to increase ALNA intake because of its potential benefits to human health. However, it is clear from earlier studies (Kelley et al. 1991; Caughey et al. 1996) that large increases in ALNA intake ( $\geqq 14 \mathrm{~g} / \mathrm{d}$ ) may not be immunologically desirable.
Subjects in the three FO groups increased their EPA+DHA intakes by approximately 220, 440 and $950 \%$ respectively. This resulted in significant $(P<0.05)$ increases in the EPA and DHA content of plasma phospholipids. This increase in EPA and DHA content was paralleled by a decrease in the content of ARA in plasma phospholipids, which occurred despite the higher ARA intake in the groups receiving the two higher doses of FO. Qualitatively, these changes in EPA, DHA and ARA content of plasma phospholipids are consistent with earlier literature (Meydani et al. 1991b; Gibney \& Hunter, 1993; Yaqoob et al. 2000; Thies et al. 2001c). The increase in EPA and DHA content was dose-dependently related to the amount of EPA or DHA provided in the capsules. Thus, the present study shows that $n-3$ PUFA of both marine and plant origin can modulate the content of EPA in plasma phospholipids. However, the degree of enrichment in EPA resulting from an increase in ALNA intake of $3.5 \mathrm{~g} / \mathrm{d}$ is less than that resulting from an increase in EPA intake of $0.27 \mathrm{~g} / \mathrm{d}$. Furthermore, while FO increases plasma phospholipid DHA content, this is not influenced by an increase in ALNA intake of $3.5 \mathrm{~g} / \mathrm{d}$.

Increasing the intake of EPA + DHA did not affect mononuclear cell proportions, lymphocyte proliferation in response to several concentrations of ConA, the production of TNF- $\alpha$ and IL- $1 \beta$ by monocytes stimulated with LPS, or the production of a range of cytokines by lymphocytes stimulated with ConA. These findings appear to contrast with previous studies (Endres et al. 1989, 1993; Meydani et al. 1991b, 1993; Molvig et al. 1991; Virella et al. 1991; Gallai et al. 1993; Caughey et al. 1996; Kelley et al. 1998, 1999). However, the previous studies used greater amounts of EPA + DHA $(2 \cdot 4-6 \cdot 0 \mathrm{~g} / \mathrm{d})$ than used here. Some other studies using low amounts of EPA + DHA $(0.55-1.60 \mathrm{~g} / \mathrm{d})$ report no effects on the production of TNF- $\alpha$ and IL-1 $\beta$ by monocytes stimulated with LPS (Molvig et al. 1991; Cooper et al. 1993; Schmidt et al. 1996; Thies et al. 2001a), or on the production of IL-2 and IFN- $\gamma$ by lymphocytes stimulated with ConA (Meydani et al. 1993; Thies et al. 2001b). Taken together, 
these findings suggest that the dose of EPA + DHA is important, and that in the current study even the highest dose used was insufficient to influence these mononuclear cell responses. However, two studies report that $1.2 \mathrm{~g}$ $(\mathrm{EPA}+\mathrm{DHA}) / \mathrm{d}$ for 12 or 24 weeks resulted in a significant reduction in proliferation of lymphocytes (Meydani et al. 1993; Thies et al. 2001b). There are three possible explanations for this apparent contradiction. The first is age: in the current study the subjects were young ( $<39$ years), whereas in the earlier studies (Meydani et al. 1993; Thies et al. 2001b) subjects were elderly (mean age 65 years). It is possible that immune cells of older subjects are more sensitive to the effects of $n-3$ PUFA. This is supported by observations of Meydani et al. (1991b), studying young and older women: $2.4 \mathrm{~g}$ (EPA + DHA)/d significantly decreased proliferation of lymphocytes from the older women, whereas there was no effect on those from the younger women. Thus, $n$-3 PUFA might have different immunological potencies according to age. The second factor that might contribute to contradictory effects regarding FO and lymphocyte proliferation is lipid peroxidation. Lipid peroxides inhibit lymphocyte proliferation (Begin, 1987; Madhavi et al. 1994) and might be part of the mechanism by which high intakes of $n-3$ PUFA impair this process (Kramer et al. 1991). In the study of Meydani et al. (1991b) mentioned previously, 2.4 g (EPA + DHA)/d significantly elevated plasma TBARS concentration in the older, but not the younger, women (Meydani et al. 1991a). In the current study, subjects consumed an extra $9 \mathrm{mg} \alpha$-tocopherol/d during supplementation, increasing their habitual intake by about $100 \%$. This resulted in an increase in plasma $\alpha$-tocopherol concentration in all subjects (by approximately $30 \%$ ) and there was no change in plasma TBARS concentration, indicating that the increased intake of PUFA had not increased lipid peroxidation. Thus, absence of increased lipid peroxidation in subjects in the current study may explain the lack of effect of $n$-3 PUFA on lymphocyte proliferation. Some earlier studies reporting an inhibitory effect of FO on mononuclear cell functions, such as lymphocyte proliferation, may not have provided sufficient $\alpha$-tocopherol to prevent lipid peroxidation. The third factor that might contribute to contradictory effects regarding FO and lymphocyte proliferation is the precise nature of the $n-3$ PUFA used. In the current study, the FO was rich in DHA, so that subjects received a much higher amount of DHA than EPA. In the studies of Meydani et al. (1993) and Thies et al. $(2001 b)$, the FO used was rich in EPA. Thus, the reason that there was no effect of lymphocyte proliferation in the current study may be that EPA is a more effective inhibitor of proliferation than DHA, and that the intake of EPA was insufficient to induce an effect. There is support for the idea that DHA is less inhibitory than EPA: in a study of elderly subjects, $0.75 \mathrm{~g} \mathrm{DHA} / \mathrm{d}$ did not affect lymphocyte proliferation, whereas FO providing $0.72 \mathrm{~g} \mathrm{EPA}+0.28 \mathrm{~g} \mathrm{DHA} / \mathrm{d}$ was inhibitory (Thies et al. $2001 b$ ). Future studies should seek to discriminate between the effects of EPA and DHA on immune and inflammatory functions, and to identify whether the EPA: DHA ratio in FO is important in determining its biological effects.
The one significant effect on mononuclear cell responses observed in the current study was the reduction in IL-6 production after supplementation with the two higher doses of FO. An earlier study reported no effect of $0.55 \mathrm{~g}$ (EPA + DHA)/d on IL-6 production by LPS-stimulated monocytes (Schmidt et al. 1996). Meydani et al. (1991b) reported 60 and $30 \%$ decreases in IL-6 production by ConA-stimulated PBMC from older and younger women respectively, after $2.4 \mathrm{~g}(\mathrm{EPA}+\mathrm{DHA}) / \mathrm{d}$. In elderly subjects, $1.2 \mathrm{~g}$ (EPA + DHA)/d was reported to decrease IL-6 production by ConA-stimulated PBMC by $35 \%$ (Meydani et al. 1993). The current study is in general agreement with these earlier studies, in that it demonstrates no significant effect of $0.44 \mathrm{~g}(\mathrm{EPA}+\mathrm{DHA}) / \mathrm{d}$ and a significant $(P<0.05)$ effect of 0.94 and $1.90 \mathrm{~g}(\mathrm{EPA}+\mathrm{DHA}) / \mathrm{d}$. However, the current study extends these earlier studies by identifying that the threshold dose at which $n$-3 PUFA are able to significantly $(P<0.05)$ decrease IL-6 production is between 0.44 and $0.94 \mathrm{~g}(\mathrm{EPA}+\mathrm{DHA}) / \mathrm{d}$. Whether this effect is due to EPA or DHA is not immediately apparent. Nevertheless, the observation of a significant effect of FO on IL-6 production, but not on the production of other cytokines in response to either LPS or ConA, indicates that different components of the mononuclear cell response to stimulation have different sensitivities to increased supply of long-chain $n$-3 PUFA. This suggests that there may be subtle differences in the mechanism by which n-3 PUFA influence the production of different cytokines.

An excessive production of IL- 6 has been noted in patients with sepsis, burns and trauma (Pape et al. 2000; Spittler et al. 2000) and in chronic inflammatory diseases such as rheumatoid arthritis (Dasgupta et al. 1992). The ability of a modest intake of FO to decrease IL-6 production by PBMC suggests that administration of longchain $n$-3 PUFA might be a useful therapeutic strategy in these conditions (see Calder, 2002).

An unexpected finding in the current study was the reduction in lymphocyte proliferation in all groups at 12 weeks compared with baseline. This may be due to seasonal factors, which have been shown to exert a particularly strong effect on $\mathrm{T}$ lymphocyte proliferation. For example, ConA-stimulated proliferation of PBMC from male rhesus monkeys housed under natural lighting conditions was about $80 \%$ less in summer than in winter (Mann et al. 2000), an effect also observed for lymphocytes from mice (for review, see Nelson \& Demas, 1996).

In summary, the current study suggests that modest levels of either plant- or marine-derived $n$-3 PUFA do not influence circulating mononuclear cell numbers and do not impair most functional responses of these cells over a 12-week period. Thus, it appears that consumption of $n-3$ PUFA could be increased in accordance with recommendations, without inducing adverse effects on these components of the immune system and thus on the ability of individuals to mount a successful immune response. However, the current study was conducted in male subjects aged 18-39 years and the findings should not be extrapolated to other groups such as the elderly, infants or pregnant women. It will be important to conduct similar dose response studies of the effect of $n-3$ PUFA on immune function in groups other than that studied here. 


\section{Acknowledgements}

This research was supported by a grant to P. C. C. from the Biotechnology and Biological Sciences Research Council (grant no. 51/D05696). F. A. W. was supported by a postgraduate studentship from Rank Prize Funds. Flow cytometry facilities were provided by a grant to P. C. C. from the Medical Research Council under the JREI Scheme (G9717948).

\section{References}

Abbas AK, Lichtman AH \& Pober JS (1994) Cellular and Molecular Immunology, 2nd ed., Philadelphia, PA: WB Saunders Company.

Begin ME (1987) Effects of polyunsaturated fatty acids and of their oxidation products on cell survival. Chemistry and Physics of Lipids 45, 269-313.

Blok WL, Deslypere J-P, Demacker PNM, van der VenJongekrijg J, Hectors MPC, van der Meer JMW \& Katan MB (1997) Pro- and anti-inflammatory cytokines in healthy volunteers fed various doses of fish oil for 1 year. European Journal of Clinical Investigation 27, 1003-1008.

British Nutrition Foundation (1992) Report of the Task Force on Unsaturated Fatty Acids: Nutritional and Physiological Significance. London: Chapman \& Hall.

British Nutrition Foundation (1999) Briefing Paper: n-3 Fatty Acids and Health. London: British Nutrition Foundation.

Calder PC (2001a) Polyunsaturated fatty acids, inflammation and immunity. Lipids 36, 1007-1024.

Calder PC (2001b) N-3 polyunsaturated fatty acids, inflammation and immunity: pouring oil on troubled waters or another fishy tale? Nutrition Research 21, 309-341.

Calder PC (2002) Dietary modification of inflammation with lipids. Proceedings of the Nutrition Society 61, 345-358.

Caughey GE, Mantzioris E, Gibson RA, Cleland LG \& James MJ (1996) The effect on human tumour factor $\alpha$ and interleukin $1 \beta$ production of diets enriched in $n$-3 fatty acids from vegetable oil or fish oil. American Journal of Clinical Nutrition 63 , $116-122$.

Cooper AL, Gibbons L, Horan MA, Little RA \& Rothwell NJ (1993) Effect of dietary fish oil supplementation on fever and cytokine production in human volunteers. Clinical Nutrition 112, 321-328.

Dasgupta B, Corkill M, Kirkham B, Gibson T \& Panayi G (1992) Serial estimation of interleukin-6 as a measure of systemic disease in rheumatoid arthritis. Journal of Rheumatology 19, 22-25.

de Deckere EAM, Korver O, Vershuren PM \& Katan MB (1998) Health aspects of fish and $n-3$ polyunsaturated fatty acids from plant and marine origin. European Journal of Clinical Nutrition 52, 749-753.

Emken EA, Adlof RO \& Gulley RM (1994) Dietary linoleic acid influences desaturation and acylation of deuterium-labeled linoleic acid and linolenic acids in young adult males. Biochimica et Biophysica Acta 1213, 277-288.

Endres S, Ghorbani R, Kelley VE, Georgilis K, Lonnemann G, van der Meer JMW, Cannon JG, Rogers TS, Klempner MS, Weber PC, Schaeffer EJ, Wolff SM \& Dinarello CA (1989) The effect of dietary supplementation with $n-3$ polyunsaturated fatty acids on the synthesis of interleukin-1 and tumour necrosis factor by mononuclear cells. New England Journal of Medicine 320, 265-271.

Endres S, Meydani SN, Ghorbani R, Schindler R \& Dinarello CA (1993) Dietary supplementation with $n$-3 fatty acids suppresses interleukin-2 production and mononuclear cell proliferation. Journal of Leukocyte Biology 54, 599-603.
Finnegan YE, Minihane AM, Leigh-Firbank EC, Kew S, Meijer GW, Muggli R, Calder PC \& Williams CM (2003) Plant and marine derived $n-3$ polyunsaturated fatty acids have differential effects on fasting and postprandial blood lipids and susceptibility of low density lipoprotein to oxidative modification in moderately hyperlipidemic subjects. American Journal of Clinical Nutrition (In the Press).

Gallai V, Sarchielli P, Trequattrini A, Franceschini M, Floidi A, Firenze C, Alberti A, Di Benedetto D \& Stragliotto E (1993) Cytokine secretion and eicosanoid production in the peripheral blood mononuclear cells of MS patients undergoing dietary supplementation with $n-3$ polyunsaturated fatty acids. Journal of Neuroimmunology 56, 143-153.

Gibney MJ \& Hunter B (1993) The effects of short term and long term supplementation with fish oil on the incorporation of $n-3$ polyunsaturated fatty acids into cells of the immune system in healthy volunteers. European Journal of Clinical Nutrition 47, 255-259.

Healy DA, Wallace FA, Miles EA, Calder PC \& Newsholme P (2000) Effect of low to moderate amounts of dietary fish oil on neutrophil lipid composition and function. Lipids 35, 763-768.

Indu M \& Ghafoorunissa (1992) n-3 Fatty acid in Indian diets comparison of the effect of precursor (alpha-linolenic acid) vs product (long-chain $n-3$ polyunsaturated fatty acids). Nutrition Research 12, 569-582.

Kelley DS, Branch LB, Love JE, Taylor PC, Rivera YM \& Iacono JM (1991) Dietary alpha-linolenic acid and immunocompetance in humans. American Journal of Clinical Nutrition 53, 40-46.

Kelley DS, Taylor PC, Nelson GJ \& Mackey BE (1998) Dietary docosahexaenoic acid and immunocompetence in young healthy men. Lipids 33, 559-566.

Kelley DS, Taylor PC, Nelson GJ, Schmidt PC, Ferretti A, Erickson KL, Yu R \& Chandra RK (1999) Docosahexaenoic acid ingestion inhibits natural killer cell activity and production of inflammatory mediators in young healthy men. Lipids $\mathbf{3 4}$, $317-324$.

Kramer TR, Schoene N, Douglass LW, Judd JT, Ballard-Barbash R, Taylor PR, Bhagavan HN \& Nair PP (1991) Increased vitamin $\mathrm{E}$ intake restores fish oil induced suppressed blastogenesis of mitogen-stimulated lymphocytes. American Journal of Clinical Nutrition 54, 896-902.

Li D, Sinclair AJ, Wilson A, Nakkote S, Kelly F, Abedin L, Mann N \& Turner A (1999) Effect of dietary alpha-linolenic acid on thrombotic risk factors in vegetarian men. American Journal of Clinical Nutrition 69, 872-882.

Licastro F, Davis LJ \& Morini MC (1993) Lectins and superantigens - membrane interactions of these compounds with T-lymphocytes affect immune responses. International Journal of Biochemistry 25, 845-852.

Madhavi N, Das UN, Prabha PS, Kumar GS, Koratkar R \& Sagar PS (1994) Suppression of human T-cell growth in vitro by cisunstaurated fatty acids - relationship to free radicals and lipid peroxidation. Prostaglandins Leukotrienes and Essential Fatty Acids 51, 33-40.

Mann DR, Akinbami MA, Gould KG \& Ansari AA (2000) Seasonal variation in cytokine expression and cell-mediated immunity in male rhesus monkeys. Cellular Immunology 200, $105-115$.

Mantzioris E, James MJ, Gibson RA \& Cleland LG (1994) Dietary substitution with an alpha-linolenic acid rich vegetable oil increases eicosapentaenoic acid concentrations in tissues. American Journal of Clinical Nutrition 59, 1304-1309.

Mantzioris E, James MJ, Gibson RA \& Cleland LG (1995) Differences exist in the relationships between dietary linoleic and $\alpha$-linolenic acids and their respective long-chain metabolites. American Journal of Clinical Nutrition 61, 320-324. 
Meydani M, Natiello F, Goldin B, Free N, Woods M, Schaefer E, Blumberg JB \& Gorbach SL (1991a) Effect of long-term fish oil supplementation on vitamin E status and lipid peroxidation in women. Journal of Nutrition 121, 484-491.

Meydani SN, Endres S, Woods MM, Goldin BR, Soo C, MorrilLabrode A, Dinarello C \& Gorbach SL (1991b) Oral (n-3) fatty acid supplementation suppresses cytokine and lymphocyte proliferation: comparison between young and older women. Journal of Nutrition 121, 547-555.

Meydani SN, Lichtenstein AH, Cornwall S, Meydani M, Goldin BR, Rasmussen H, Dinarello CA \& Schaffer EJ (1993) Immunologic effects of national cholesterol education step-2 diets with and without fish-derived $n-3$ fatty acid enrichment. Journal of Clinical Investigation 92, 105-113.

Molvig J, Pociot F, Worsaae H, Wogensen LD, Baek L, Christensen P, Mandruppoulsen T, Andersen K, Madsen P, Dyerberg J \& Nerup J (1991) Dietary supplementation with omega 3 polyunsaturated fatty acids decreases mononuclear cell proliferation and interleukin 1 beta content but not monokine secretion in healthy and insulin dependent diabetic individuals. Scandinavian Journal of Immunology 34, 399-410.

Nelson RJ \& Demas GE (1996) Seasonal changes in immune function. Quarterly Review of Biology 71, 511-548.

Pape HC, Schmidt RE, Rice J, van Griensven M, das Gupta R, Krettek C \& Tscherne H (2000) Biochemical changes after trauma and skeletal surgery of the lower extremity: quantification of the operative burden. Critical Care Medicine 28, 3441-3448.

Sanders TAB \& Roshanai F (1983) The influence of different types of $\omega-3$ polyunsaturated fatty acids on blood lipids and platelet function in healthy volunteers. Clinical Science 64, 91-99.

Sanders TAB \& Younger K (1981) The effects of dietary supplements of $\omega-3$ polyunsaturated fatty acids on the fatty acid composition of platelets and plasma choline phosphoglycerides. British Journal of Nutrition 45, 613-617.
Schmidt EB, Varming K, Moller JM, Bulow Pederson I, Madsen P \& Dyerberg J (1996) No effect of very low dose $n-3$ fatty acids on monocyte function in healthy humans. Scandinavian Journal of Clinical Investigation 56, 87-92.

Spittler A, Razenberger M, Kupper H, Kaul M, Boltz-Nitulescu G, Fugger RF \& Roth E (2000) Relationship between interleukin-6 plasma concentration in patients with sepsis, monocyte phenotype, moncyte phagocytic properties, and cytokine production. Clinical Infectious Diseases 21, 1338-1342.

Thies F, Miles EA, Nebe-von-Caron G, Powell JR, Hurst TL, Newsholme EA \& Calder PC (2001a) Influence of dietary supplementation with long-chain $n-3$ or $n-6$ polyunsaturated fatty acids on blood inflammatory cell populations and functions and on plasma soluble adhesion molecules in healthy humans. Lipids 36, 1183-1193.

Thies F, Nebe-von-Caron G, Powell JR, Yaqoob P, Newsholme EA \& Calder PC (2001b) Dietary supplementation with gamma linolenic acid or fish oil decreases $\mathrm{T}$ lymphocyte proliferation in healthy older humans. Journal of Nutrition 131, 1918-1927.

Thies F, Nebe-von-Caron G, Powell JR, Yaqoob P, Newsholme EA \& Calder PC (2001c) Dietary supplementation with eicosapentaenoic acid, but not with other long-chain $n 3$ or $n 6$ polyunsaturated fatty acids, decreases natural killer cell activity in healthy subjects aged $>55 \mathrm{y}$. American Journal of Clinical Nutrition 73, 539-548.

Virella G, Fourspring K, Hyman B, Haskill-Stroud R, Long L, Virella I, La Via M, Gross AJ \& Lopes-Virella M (1991) Immunosuppressive effects of fish oil in normal human volunteers: Correlation of the in vitro effects of eicosapentaenoic acid on human lymphocytes. Clinical Immunology and Immunopathology 61, 161-176.

Yaqoob P, Pala HS, Cortina-Borja M, Newsholme EA \& Calder PC (2000) Encapsulated fish oil enriched in $\alpha$-tocopherol alters plasma phospholipid and mononuclear cell fatty acid compositions but not mononuclear cell functions. European Journal of Clinical Investigation 30, 260-274. 